\title{
Comparison Between Vegetation Index Obtained by Active and Passive Proximal Sensors
}

\author{
Victor Hugo Rohden Prudente (Corresponding author) \\ National Institute for Space Research (INPE), São José dos Campos, Brazil \\ E-mail: victor.rohden@yaho.com
}

Erivelto Mercante, Jerry Adriani Johann

Graduate Program in Agricultural Engineering (PGEAGRI), Western Paraná State University (UNIOESTE), Cascavel, Brazil

E-mails: erivelto.mercante@unioeste.br; jerry.johann@unioeste.br

Carlos Henrique Wachholz de Souza

Federal University of Paraná - UFPR, Jandaia, Brazil

E-mail: carlos_hws@hotmail.com

\section{Lucas Volochen Oldoni}

National Institute for Space Research - INPE, São José dos Campos, Brazil

E-mail: lucasoldoni@outlook.com

Luiz Almeida, Willyan Ronaldo Becker

Graduate Program in Agricultural Engineering (PGEAGRI), Western Paraná State University (UNIOESTE), Cascavel, Brazil

E-mails: almeidalz@hotmail.com; willyanbekcer@hotmail.com

Bruno Bonemberger da Silva

Agricultural Engineering, Brazil

E-mail: bruno_bornemberguer@yahoo.com.br 
Received: March 27, $2021 \quad$ Accepted: April 21, $2021 \quad$ Published: April 25, 2021

doi:10.5296/jas.v9i2.18462

URL: https://doi.org/10.5296/jas.v9i2.18462

\begin{abstract}
Proximal sensors have been used to characterize the crop biophysical properties by reflectance values and/or using Vegetation Indices (IV). Our goal with this work is to compare NDVI (Normalized Difference Vegetation Index) spectra-temporal profiles obtained by active (GreenSeeker 505 Handheld) and passive (FieldSpec4 model Standard-Res) proximal sensors to monitor soybeans and beans. It was monitored agricultural fields with soybeans Nidera 5909RG variety and beans Imperador variety, located in the municipality of Cascavel, Parana state, Brazil. The proximal sensors were used to monitor the crop's conditions on different Days After Sowing (DAS). NDVI from FieldSpec4 (NDVI FS) showed a higher correlation with GreenSeeker NDVI (NDVI GS) in the wavelengths of 649 $\mathrm{nm}$ and $771 \mathrm{~nm}$ for soybeans ( $\mathrm{rs}=0.9105)$ and $646 \mathrm{~nm}$ and $792 \mathrm{~nm}$ for beans $(\mathrm{rs}=0.9382)$. The inter-calibration of NDVI GS values in function of NDVI FS, considering the entire phenological cycle, resulted in RMSE $=0.0520$ and $\mathrm{dr}=0.8630$ for soybeans and RMSE $=$ 0.0636 and $\mathrm{dr}=0.8890$ for beans. NDVI values showed saturation during the major vegetative development of the crops, interfering in the inter-calibration process. In general, the NDVI GS and NDVI FS were similar in terms of their spectral-temporal pattern. According to our results, the active sensor could be used to crop monitoring, resulting in a lower cost and less climatic interference.
\end{abstract}

Keywords: NDVI, crop monitoring, terrestrial sensors, soybeans, beans, agriculture

\title{
1. Introduction
}

Food security is a global concern due to the continued population growth and the stagnant number of food production areas (Harfenmeister, Spengler, \& Weltzien, 2019). In this context, soybean and beans, present in many people's food base, are two of the more important crops related to the food demands. There are efforts from farmers, technical, and direct stakeholders to guarantee the maximum food production sustainably. Therefore, accurate spatial and temporal crop information is necessary (Kenduiywo, Bargiel, \& Soergel, 2016). Remote sensing data, mainly through spectro-temporal profiles, could be related to the crop biomass, allowing monitoring crop phenological development (Johann, Vieira, Lamparelli, \& Duft, 2013). However, due to the crop dynamics (Atzberger, 2013), temporal data frequency is important for periodic monitoring (Atzberger, 2013; Johann, Becker, Uribe-Opazo, \& Mercante, 2016). The Vegetation Indexes (VI) are spectro-temporal examples that could be used to express the phenological crop cycle (Almeida et al., 2015; Formaggio \& Sanches, 2017; Johann et al., 2016). NDVI (Normalized Difference Vegetation Index) is a well know VI, which was proposed by Rouse et al. (1973). Using the contrast between the red and infrared channels, NDVI is related to agronomics variables (e.g., plant height, leaf area index, dry matter, yield, intercepted photosynthetically active radiation) (Baret \& Guyot, 1991). Most of the sensors can provide NDVI values. However, the wavelengths and bandwidth 
could be different (Kim, 2010), resulting in different patterns.

Proximal (or terrestrial) sensors suffering less atmospheric interference than aerial and orbital sensors (Eberhardt et al., 2016; Prudente et al., 2020; Whitcraft, Vermote, Becker-Reshef, \& Justice, 2015) and have temporal resolution flexibility (Mulla, 2013). Some studies characterized biophysical crop proprieties using proximal VI from active and passive sensors (Anderson et al., 2016; Cattani et al., 2017; Congalton, Gu, Yadav, Thenkabail, \& Ozdogan, 2014; Prudente et al., 2019; Viana et al., 2018; Viana, Mercante, Felipetto, Kusminski, \& Bleil Jr, 2017; Yao et al., 2013). Passive sensors depend on an external electromagnetic source, as the sun (Janse \& Deshmukh, 2017), and can be grouped as multispectral or hyperspectral (hundreds of bands). With spectroradiometers (hyperspectral sensors) it is possible to obtain the spectral signature and various VIs (Congalton et al., 2014). FieldSpec4 Standard-Res (ASD, Boulder, CO, USA) is one of the most common hyperspectral sensors used in agricultural research (Cattani et al., 2017; Prudente et al., 2019; Viana et al., 2018, 2017). On the other hand, active sensors emit their energy source and they are less affected by weather conditions (Yao et al., 2013). GreenSeeker 505 Handheld (Trimble Agriculture, Westminster, USA) is one of the more popular proximal active sensors for agriculture (Stocker, Souza, Johann, Beneduzzi, \& Silva, 2019; Zheng et al., 2016).

FieldSpec4 sensor costs tens of thousands of dollars more than the GreenSeeker 505 Handheld sensor. Thus, our goal is to compare the spectro-temporal NDVI profiles obtained from both sensors for soybean and beans fields monitoring. This comparison allows us to identify the possibility of using a more affordable sensor to provide crop monitoring and propose an inter-calibration process between NDVI sensors values.

\section{Methods}

\section{Study area}

In the study, two fields were monitored in the municipality of Cascavel, Parana state, Brazil (Figure 1). This municipality is recognized due to the high technology on the farmer level (Souza, Mercante, Johann, Lamparelli, \& Uribe-Opazo, 2015) and as one of the largest national producers of soybeans, wheat, corn, and beans (IBGE, 2020). Soybeans and beans fields have areas of 78.32 ha and 40.20 ha, respectively. According to Koppen classification, both fields have a Humid subtropical climate (Cfa) (Aparecido, Rolim, Richetti, Souza, \& Johann, 2016). The soybeans field has a $6 \%$ slope (range of $1 \%$ to $15 \%$ ) and the beans field has a $7 \%$ slope (range of 2\% to 20\%) (Brasil, 2008; Embrapa, 2009). Eutrophic Red Nitosol soil type is present in the beans field and Red Dystrophic Latosol soil type is present in the soybeans field (Santos et al., 2011). 


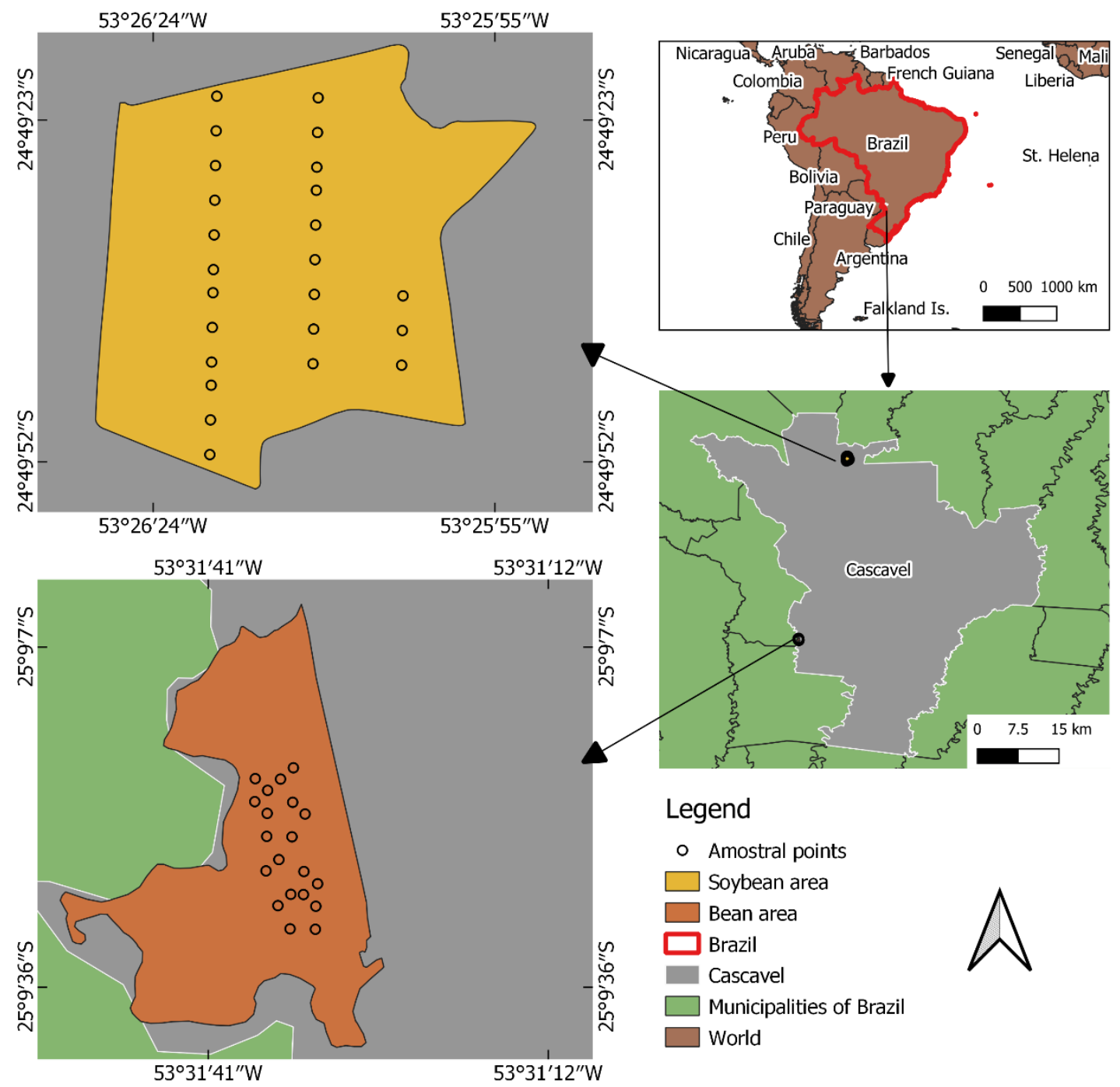

Figure 1. Soybean (top left) and beans (bottom left) locations field in the municipality of Cascavel (bottom right)

\section{Field data}

Soybeans, Nidera 5909RG variety, was sown on 2015 October $6^{\text {th }}$ and $7^{\text {th }}$ and harvested during 2016 on February $3^{\text {rd }}$ and $10^{\text {th }}$. Beans, Imperador variety, was sown on 2016 March $3^{\text {rd }}$ and $4^{\text {th }}$. However, due to a frost incident on May $1^{\text {st }}$ and $2^{\text {nd }}$ (DAS 59 and 60), beans were not harvest. Both crops had $0.45 \mathrm{~m}$ of rows spacing. In the study, were monitored 24 points on the soybeans field and 20 points on the beans field. The sampling data field was collected with 34, 45, 71, 76, and 110 Days After the Sowing (DAS) for soybean and 0, 10, 25, 43, 55, and 70 DAS for beans (Figure 2). The field missions were influenced by the climatic conditions (rainy, cloud frequency, and frost incident) as shown in Figure 3. On May $1^{\text {st }}$ and $2^{\text {nd }}$ (DAS 59 and 60) occurred a frost incident on the beans field, and the farmer removed the crop on May $16^{\text {th }}$ and $17^{\text {th }}$ (DAS 74 and 75 ). 


\section{Soybean}

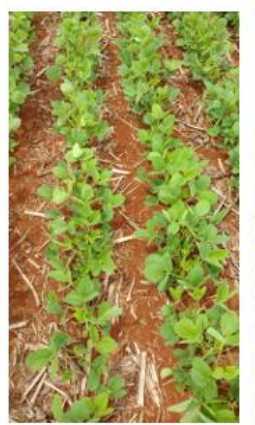

DAS 034

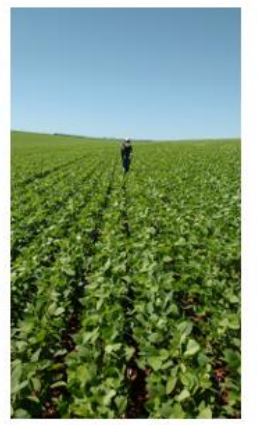

DAS 045

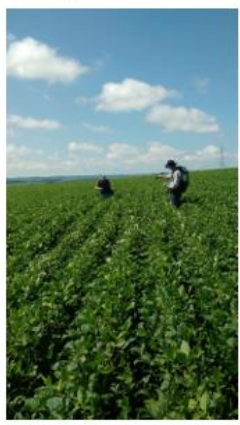

DAS 071

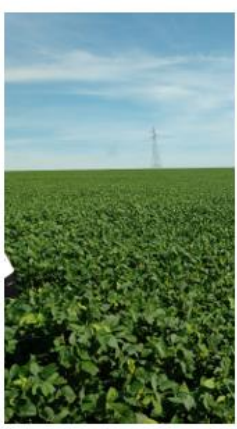

DAS 076

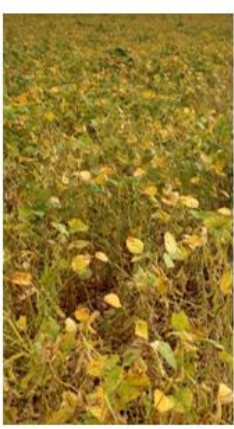

DAS 110

Bean

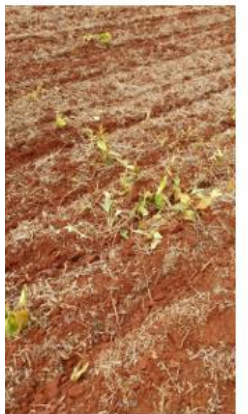

DAS 000

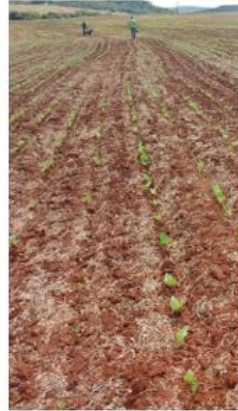

DAS 010

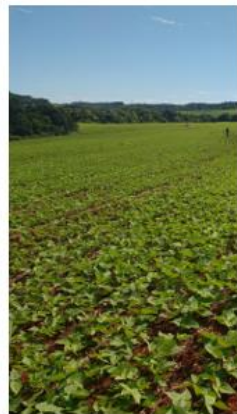

DAS 025

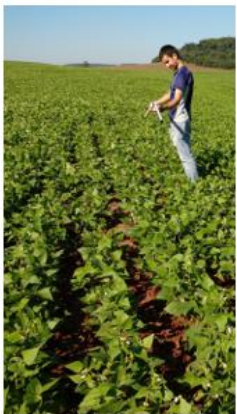

DAS 043

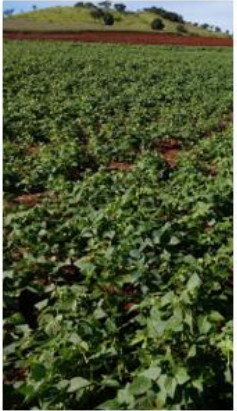

DAS 055

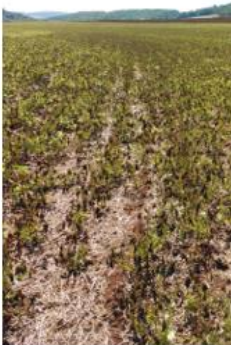

DAS 070

Figure 2. Field missions on different DAS for soybean (top) and bean (bottom)

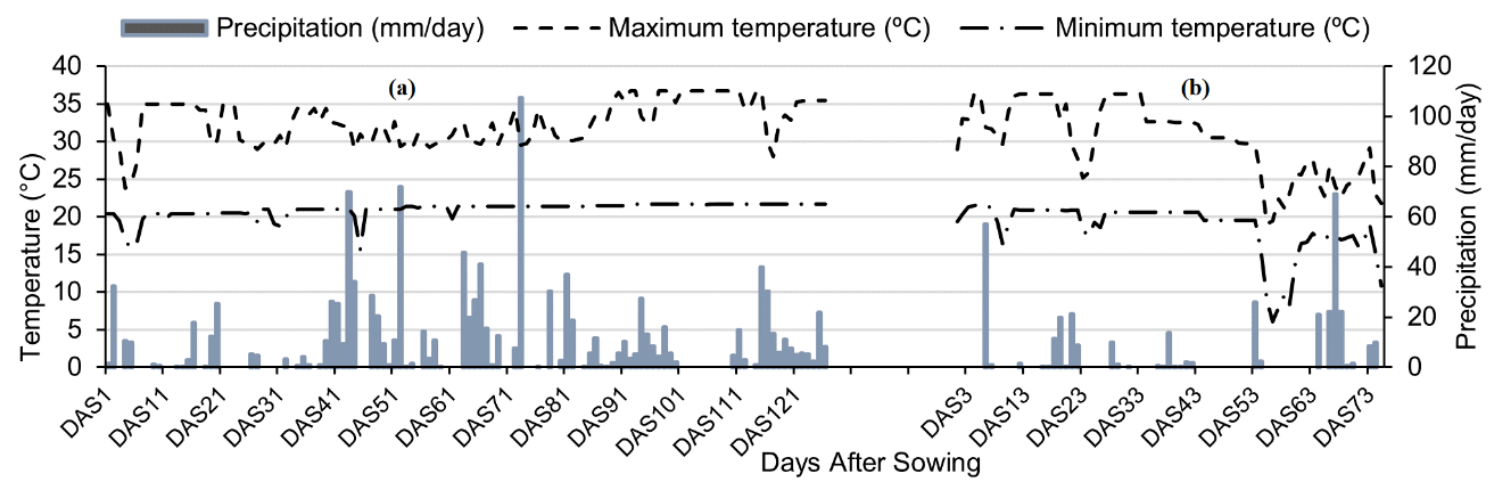

Figure. 3. Weather conditions, precipitation, and temperature during the phenological cycle of the soybean (left - a) and beans (right - b) (Princeton University, 2016)

\section{Terrestrial sensors}

The active sensor GreenSeeker 505 Handheld (Trimble Agriculture, Westminster, CO, USA) and the passive hyperspectral sensor FieldSpec4 Standard-Res model (ASD, Boulder, CO, USA) were used in the study. Few studies used these proximal sensors at the farm level in this study region (Cattani et al., 2017; Prudente et al., 2019; Viana et al., 2018), but they did not compare the NDVI values from different sensors. GreenSeeker 505 Handheld register the 
reflectance on two regions of the electromagnetic spectrum, red wavelength (RED GS centered at $0.66 \mu \mathrm{m} \pm 0.0125 \mu \mathrm{m}$ ) and near-infrared (NIR) wavelength (NIR GS - centered at $0.78 \mu \mathrm{m} \pm 0.0125$ ), both with $0.025 \mu \mathrm{m}$ of spectral resolution. This sensor also provides the NDVI values with these bands, which was called NDVI GS (TRIMBLE, 2010; Yao et al., 2013). FeldSpec 4 has a field of view (FOV) of $25^{\circ}$ and can provide data with intervals of $0.001 \mu \mathrm{m}$ in a range of $0.35-2.5 \mu \mathrm{m}$ in 0.001 intervals (ASD, 2015). To compare the NDVI for both sensors were used the same GreenSeeker 505 Handheld bands regions (red: 0.645 $\mu \mathrm{m}$ to $0.675 \mu \mathrm{m}$, and NIR: $0.765 \mu \mathrm{m}$ to $0.795 \mu \mathrm{m}$ ) to calculate the FieldSpec4 NDVI values (NDVI FS), this way has 961 different NDVI FS with the NDVI GS.

In both sensors, with a high of $0.80 \mathrm{~m}$ above the canopy, were covered $0.6 \mathrm{~m}$ horizontally on the ground (Cattani et al., 2017; Prudente et al., 2019; Stocker et al., 2019; TRIMBLE, 2010). It was provided three replicates between different crop rows for each point in each field mission (e.g, each DAS). For the GreenSeeker 505 Handheld, it was walked approximately $10 \mathrm{~m}$, with a speed average of $0.5 \mathrm{~m} . \mathrm{s}^{-1}$, recording 10 samples per second, totalizing between 150 to 200 samples for each point (Cattani et al., 2017; Sharma, Bu, Denton, \& Franzen, 2015; Zheng et al., 2016). Considering the FieldSpec4, three samples were collected for each replicate in the time (one-second peer sample), totalizing nine samples at each point (Prudente et al., 2019; Viana et al., 2018, 2017). As FieldSpec4 is a passive sensor, it was used a perfectly diffuse surface for the calibration process every 10 minutes (ASD, 2015; Viana et al., 2018).

\section{Analysis}

The data from the entire phenological cycle (all the DAS) for each crop were used in the statical approach. First, the Spearman correlation coefficient (rs), at 5\% of significance, compares the NDVI from both sensors for each crop. After, the NDVI FS with the highest correlation value with NDVI GS was used to provide the inter-calibration process, using Simple Linear Regression. Also, it provided a statical summary of the NDVI values, where the T-student test (5\% of significance) was used to analyze that the average of NDVI values was different from each sensor for each crop. To analyze the inter-calibration process, using the NDVI FS values to estimate the NDVI GS, it was used the determination coefficient $\left(\mathrm{R}^{2}\right)$, Mean Error (ME), Root Mean Square Error (RMSE). To verify the performance process, it was used the improved concordance coefficient of Willmott (Willmott, Robeson, \& Matsuura, 2012) $\left(d_{r}\right)$.

\section{Results}

All Spearman correlation (rs) among NDVI GS and NDVI FS were significant (at 5\% of significance) for soybeans and beans. The values presented no outliers for both crops (Figure 4), with a rs range of 0.897 to 0.910 for soybean and 0.925 to 0.938 for the bean. NDVI FS, using the bandwidth of $0.648 \mu \mathrm{m}$ and $0.649 \mu \mathrm{m}$ on the RED spectrum region and $0.771 \mu \mathrm{m}$ to $0.773 \mu \mathrm{m}$ on the NIR spectrum region had the highest rs values with NDVI GS to soybean, with the best rs $(0.9105)$ value to $0.649 \mu \mathrm{m}$ (RED) and $0.771 \mu \mathrm{m}$ (NIR). For beans, were identified that the bands from $0.645 \mu \mathrm{m}$ and $0.646 \mu \mathrm{m}$ on the RED spectrum and $0.790 \mu \mathrm{m}$ to $0.795 \mu \mathrm{m}$ on the NIR spectrum had better NDVI FS correlation with NDVI GS. The best rs 


\section{Mll Macrothink}

value $(0.9382)$ was achieved with $0.646 \mu \mathrm{m}$ to the RED and $0.792 \mu \mathrm{m}$ to the NIR. Therefore, were used NDVI FS with RED $0.649 \mu \mathrm{m}$ and NIR $0.771 \mu \mathrm{m}$ to soybean and RED $0.646 \mu \mathrm{m}$ and NIR $0.792 \mu \mathrm{m}$ to beans.

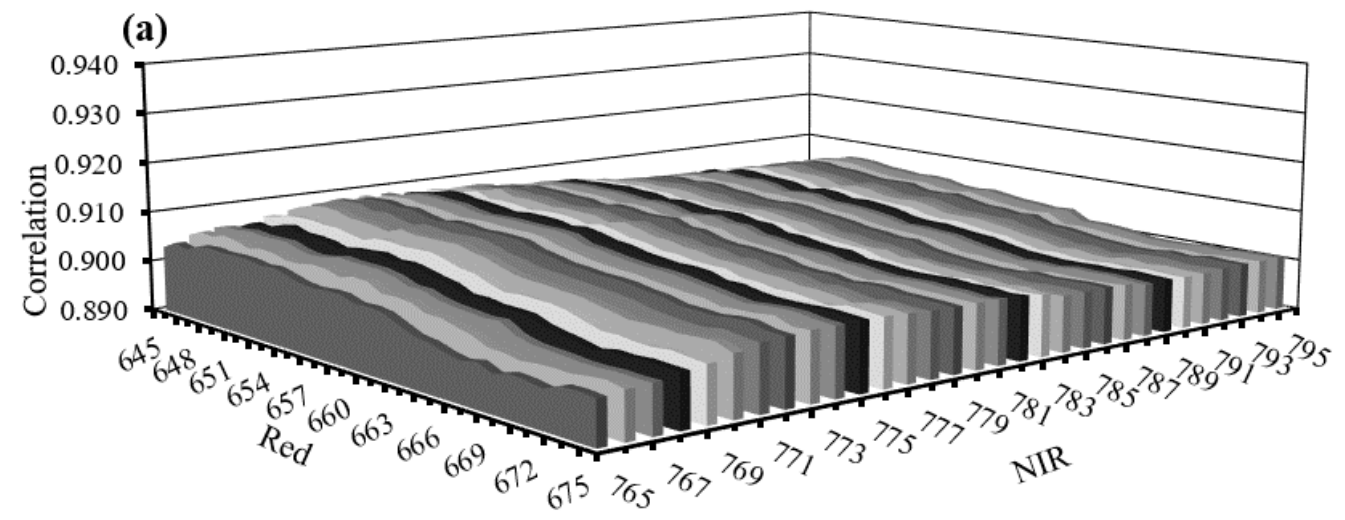

(b)

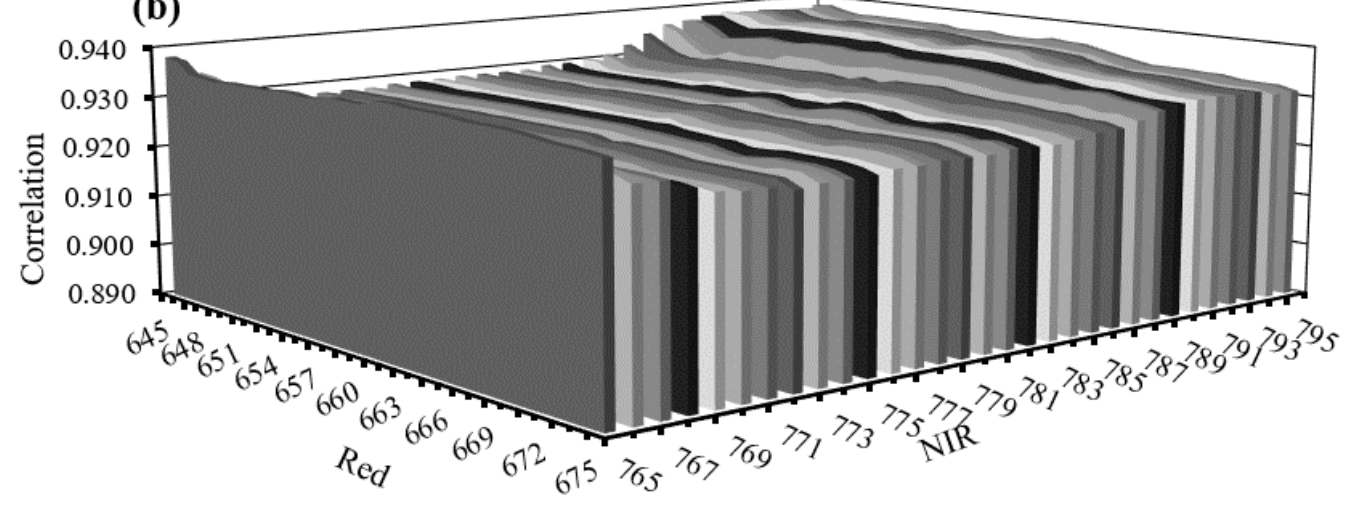

Figure 4. Spearman correlations (rs) between NDVI GS and each NDVI FS wavelength for soybean (a) and bean (b)

NDVI GS and NDVI FS had a similar spectro-temporal pattern for each crop (Figure 5). However, each crop had different NDVI patterns. Moreover, the NDVI FS has a higher range than NDVI GS for both crops. Analyzing each DAS, soybean had the highest NDVI values for the DAS 71 in both sensors (Figure 5), and in the DAS 34 and DAS 110 occurred the lower NDVI values from NDVI GS and NDVI FS, respectively. For beans, the higher NDVI values identified on the DAS 55 the lower on the DAS 0 and DAS 10 for both sensors (Figure 5). These lower NDVI values for beans were expected due to the straw in the soil, without vegetation contribution.

Positive and significant rs values were found between NDVI GS and NDVI FS for the entire soybean (0.9105) and bean (0.9382) crop cycle, as shown in Figure 5. For each DAS (Figure 5), the NDVI was correlated for the beginning and end of the soybean crop cycle (DAS 34 and DAS 110). Between the DAS 45 and 76 occurred the NDVI saturation, with a small value variation, resulting in a not significant rs. The beans showed more significant rs for DAS than soybean, with a higher value from the DAS 25 and DAS 43. Besides, the not significant NDVI rs for beans occurred on the first (DAS 0) and last (DAS 70) fieldwork, corresponding to the sown and after frost event, respectively. According to the T-student test 
at $5 \%$ of significance, NDVI GS and NDVI FS values for the entire phenological cycle were different to the soybean and equal to the bean. Considering the NDVI means for each DAS, soybean had equal NDVI values only to the DAS 34 and DAS 110. To the beans, the last two DAS (DAS 55 and 70) were different for NDVI GS and NDVI FS.
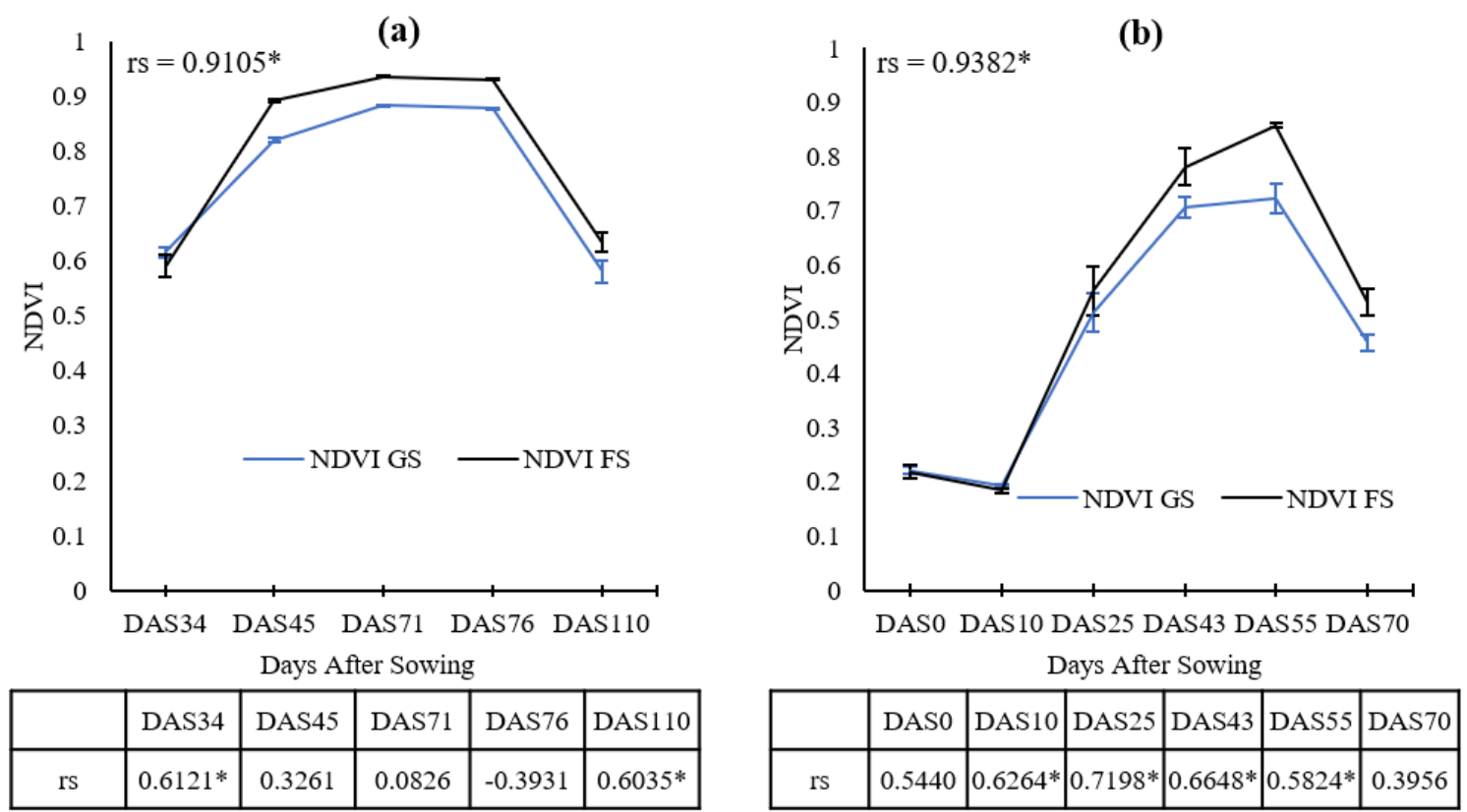

Figure 5. Spectro-temporal profiles with standard error bars and spearman correlation for NDVI from both sensors to soybean (a) and bean (b). *5\% significance; rs: Spearman correlation

The NDVI FS adjustment in the NDVI GS function shown $\mathrm{R}^{2}$ of 0.8619 to the soybeans and 0.9168 to the beans (Figure 6). Moreover, the $d_{r}$ values around 0.9 for both crops indicate that the NDVI values registered for both sensors are related. Beans show higher $\mathrm{R}^{2}$ e $\mathrm{d}_{\mathrm{r}}$ and lower ME and RMSE values than soybean (Figure 6). The NDVI GS adjusted values (Figure 6) had lower errors and the highest $d_{r}$ values (Figure 6). This means that the adjusted and observed NDVI GS values were similar. It was found three clusters between the observed and adjusted NDVI GS values (Figure 6), corresponding to the DAS 45, DAS 71, and DAS 76. During these DAS, the soybean canopy fully covers the soil between the rows, minimizing the soil response, become the majority contribute to the NDVI values near 0.90. Besides, had a sudden NDVI variation during the DAS 45 to DAS 76, with a coefficient of variation lower than $2 \%$. 

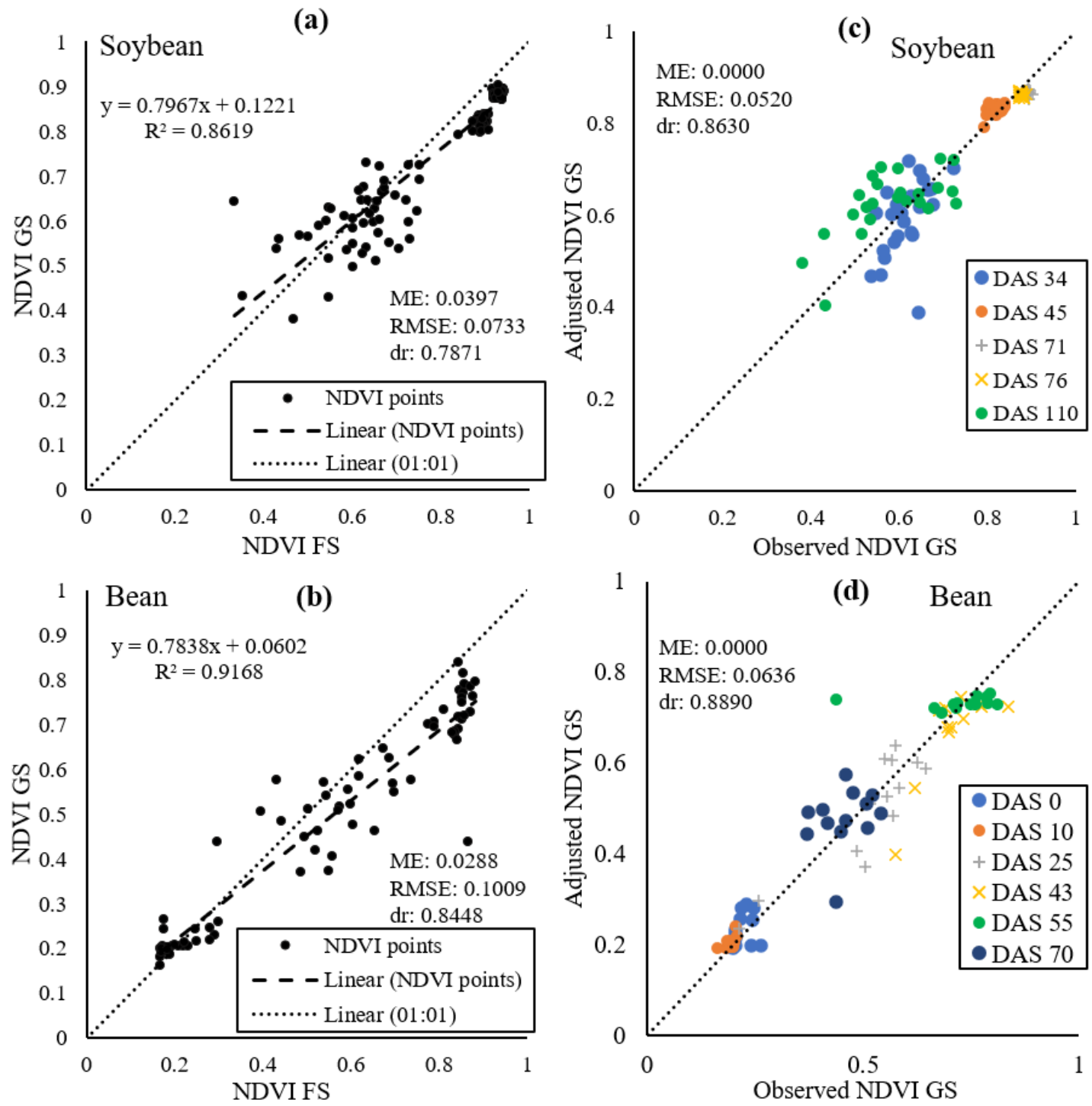

Figure 6. Scatterplot between the NDVI GS and NDVI FS collected in the field from soybean (a) and bean (b), on the left, and scatterplot between the NDVI values observed and adjusted to soybean (c) and bean (d), on the right. $\mathrm{R}^{2}$ : Determination coefficient; ME: Mean Error;

RMSE: Root Mean Square Error e dr: improved concordance coefficient of Willmott

Considering the DAS (Table 1), the concordance between observed and adjusted soybean NDVI GS values was lower than beans. The negative $d_{r}$ values to the DAS 71 and 76 to the soybean (Table 1), representing a discordance between the observed and adjusted NDVI values for some DAS. That could be due to the saturation factor, mentioned before. For beans, the first and last two DAS had lower $d_{r}$ values (Table 1), which could be related to the insignificance of crop presence (e.g., small plant height, sown period, etc., to the DAS 0 and DAS 10) and the frost occurrence (DAS 70). In general, was not observe the NDVI saturation in the bean fields. This because the NDVI values were influenced by lower biomass, less dense canopy, and the soil contribution between rows (Figure 2). 
Table 1. Statics of comparison between the adjusted and observed NDVI GS values for each DAS in the soybean and bean fields

\begin{tabular}{|c|c|c|c|c|c|c|c|}
\hline \multicolumn{4}{|c|}{ Soybean } & \multicolumn{4}{|c|}{ Bean } \\
\hline DAS & ME & RMSE & $d_{r}$ & DAS & ME & RMSE & dr \\
\hline DAS 34 & 0.0230 & 0.0723 & 0.3007 & $D A S O$ & -0.0105 & 0.0370 & 0.1895 \\
\hline$D A S 45$ & -0.0125 & 0.0182 & 0.4182 & DAS 10 & -0.0109 & 0.0161 & 0.2359 \\
\hline$D A S 71$ & 0.0214 & 0.0228 & -1.2037 & $D A S 25$ & -0.0181 & 0.0611 & 0.7111 \\
\hline$D A S 76$ & 0.0139 & 0.0159 & -1.1671 & $D A S 43$ & 0.0343 & 0.0688 & 0.4398 \\
\hline \multirow[t]{2}{*}{ DAS 110} & -0.0461 & 0.0848 & 0.5512 & DAS 55 & -0.0103 & 0.0923 & 0.5570 \\
\hline & & & & DAS 70 & -0.0207 & 0.0752 & 0.3164 \\
\hline
\end{tabular}

ME: Mean Error; RMSE: Root Mean Square Error e dr: improved concordance coefficient of Willmott.

\section{Discussion}

Soybeans and beans had similar active and passive NDVI patterns. At the beginning and end of the crop cycle (Figure 5a and Figure 5b) the soil fraction contribution is more evident, resulting in lower NDVI. This soil fraction is more present in the bean field, resulting in small NDVI values than the soybean field. Besides, for beans, monitoring started during the sown period and for soybean, it started on the DAS 34 when the canopy has grown up and attenuated the soil contribution.

In the inter-calibration process, the NDVI values showed more similar to the beans than to the soybeans, in both sensors. Yao et al. (2013) studying winter wheat in China, also found a strong relation between NDVI from active (GreenSeeker) and passive (FieldSpec4) terrestrial sensors. These authors found the equation $\mathrm{y}=1.076 \mathrm{x}-0.362$, with $\mathrm{R}^{2}$ : 0.896 and RMSE: 0.056 , been similar to our results. However, due to the NDVI saturation, the soybean development is not well represented for the higher NDVI values. This NDVI limitation in the dense canopy as soybean is well recognized in several studies (Feng et al., 2016; Liu et al., 2018; Sun, Fang, Liu, \& Ye, 2017; Yao et al., 2013; Zheng et al., 2016). As beans had a small canopy than soybean, not covering the space between rows, was not possible to identify this limitation on the bean field. Besides, the number of rainy days (Figure 3) during the soybean vegetative crop cycle was a limitation to have more DAS and improve the spectro-temporal characterization.

The NDVI FS had higher values than NDVI GS, with a statistical difference to the soybean. 
This could be due to the data acquisition scheme, where FieldSpec4 was collected statically, against the dynamic way from the GreenSeeker 505 Handheld. NDVI FS is related to statics points, NDVI GS is related to tracks/lanes, being more subject to the field heterogeneity (e.g, soil presence, and different canopy sizes). Thus, as bigger the canopy more significant was the difference between NDVI FS and NDVI GS. The highest differences between NDVI FS and NDVI GS were found from DAS 45 to DAS 76 in the soybean fields, and from DAS 55 to DAS 70 in the bean fields, resulting in a statical different average of NDVI values in these DAS. Moreover, each sensor's Spectral Response Function is different and results in different reflectance registered in the same environmental conditions. Therefore, has different reflectance values for the same canopy and, consequently, different NDVI.

The results have shown that it is possible to monitor the soybean and bean with the NDVI from the different sensors with similar results. GreenSeeker 505 Handheld and FieldSpec4 were used in several studies (Cattani et al., 2017; Prudente et al., 2019; Viana et al., 2018, 2017) to monitor the spectro-temporal development of different crops and estimate biophysical parameters. According to Zheng et al. (2016) and Prudente et al. (2019), the active sensor shows better results to monitor the crop phenological stages and biophysical parameters. One of the factors that could influence is that the passive sensor depends on the solar radiation, and may suffer the calibration process's interference. GreenSeeker is way cheaper than the FieldSepc4 sensor, corresponding an affordable way to monitor the soybean and bean through the NDVI profiles. However, FieldSpec4 has hundred of data in different spectral regions and can provide more crop information.

\section{Conclusion}

The NDVI GS and NDVI FS had similar spectro-temporal patterns and were found a strong concordance correlation, around 0.9, between the NDVI from the different sensors from soybean and beans. Hence this indicates the possibility of providing the intercalibrate process, which can be used NDVI from one sensor to estimate the NDVI values to the other sensor. However, this process was less effective after occurs the soybean closed canopy with no visible soil, due to the NDVI saturation process. Therefore, the GreenSeeker 505 Handheld is useful in providing the soybeans and beans monitoring with the NDVI and had a more affordable cost. Future researches with all FieldSpec4 and more crop types are encouraged.

\section{Acknowledgments}

This study was financed in part by the Coordenação de Aperfeiçoamento de Pessoal de Nivel Superior - Brasil (CAPES) - Finance Code 001 and the National Council for Scientific and Technological Development (CNPq). We thank the Agroindustrial Cooperative of Cascavel (COOPAVEL) and Plantar Agrícola for making the monitored areas available for study; and the Western Paraná State University-Brazil for the research support.

\section{References}

Almeida, A. Q. de, Ribeiro, A., Delgado, R. C., Rody, Y. P., Oliveira, A. S. de, \& Leite, F. P. (2015). Índice de Área Foliar de Eucalyptus Estimado por Índices de Vegetação Utilizando Imagens TM - Landsat 5. Floresta e Ambiente, 22(3), 368-376. 
https://doi.org/10.1590/2179-8087.103414

Anderson, H. B., Nilsen, L., Tømmervik, H., Karlsen, S. R., Nagai, S., \& Cooper, E. J. (2016). Using ordinary digital cameras in place of near-infrared sensors to derive vegetation indices for phenology studies of High Arctic vegetation. Remote Sensing, 8(10). https://doi.org/10.3390/rs8100847

Aparecido, L. E. de O., Rolim, G. de S., Richetti, J., Souza, P. S. de, \& Johann, J. A. (2016). Köppen, Thornthwaite and Camargo climate classifications for climatic zoning in the State of Paraná, Brazil. Ciência e Agrotecnologia, 40(4), 405-417. https://doi.org/10.1590/1413-70542016404003916

ASD, I. (2015). FieldSpec4 (p. 87). p. 87. Boulder: PANalytical.

Atzberger, C. (2013). Advances in Remote Sensing of Agriculture: Context Description, Existing Operational Monitoring Systems and Major Information Needs. Remote Sensing, 5(2), 949-981. https://doi.org/10.3390/rs5020949

Baret, F., \& Guyot, G. (1991). Potentials and limits of vegetation indices for LAI and APAR assessment. Remote Sensing of Environment, 35(2-3), 161-173. https://doi.org/10.1016/0034-4257(91)90009-U

Brasil. (2008). Topodata: banco de dados geomorfométricos do Brasil. São José dos Campos, SP: Instituto Nacional de Pesquisas Espaciais (INPE).

Cattani, C. E. V., Garcia, M. R., Mercante, E., Johann, J. A., Correa, M. M., \& Oldoni, L. V. (2017). Spectral-temporal characterization of wheat cultivars through NDVI obtained by terrestrial sensors. Revista Brasileira de Engenharia Agrícola e Ambiental, 21(11), 769-773. https://doi.org/10.1590/1807-1929/agriambi.v21n11p769-773

Congalton, R., Gu, J., Yadav, K., Thenkabail, P., \& Ozdogan, M. (2014). Global Land Cover Mapping: A Review and Uncertainty Analysis. Remote Sensing, 6(12), 12070-12093. https://doi.org/10.3390/rs61212070

Eberhardt, I. D. R., Schultz, B., Rizzi, R., Sanches, I. D., Formaggio, A. R., Atzberger, C., ... Luiz, A. J. B. (2016). Cloud cover assessment for operational crop monitoring systems in tropical areas. Remote Sensing, 8(3), 1-14. https://doi.org/10.3390/rs8030219

Embrapa, E. B. de P. A. (2009). Sistema Brasileiro de Classificação de Solos (2nd ed.). https://doi.org/ISBN 978-85-7035-198-2

Feng, W., Zhang, H.-Y., Zhang, Y.-S., Qi, S.-L., Heng, Y.-R., Guo, B.-B., ... Guo, T.-C. (2016). Remote detection of canopy leaf nitrogen concentration in winter wheat by using water resistance vegetation indices from in-situ hyperspectral data. Field Crops Research, 198, 238-246. https://doi.org/10.1016/j.fcr.2016.08.023

Formaggio, A. R., \& Sanches, I. D. (2017). Sensoriamento Remoto em Agricultura. São José dos Campos - SP: Eficina de Textos.

Harfenmeister, K., Spengler, D., \& Weltzien, C. (2019). Analyzing Temporal and Spatial 
Characteristics of Crop Parameters Using Sentinel-1 Backscatter Data. Remote Sensing, 11(13), 1569. https://doi.org/10.3390/rs11131569

IBGE, I. B. de G. e E. (2020). Banco de dados agregados.

Janse, P. V., \& Deshmukh, R. R. (2017). Hyperspectal Remote Sensing for Agriculture: A Review. International Journal of Computer Applications, 172(7), 30-34.

Johann, J. A., Becker, W. R., Uribe-Opazo, M. A., \& Mercante, E. (2016). Uso de imagens do sensor orbital modis na estimação de datas do ciclo de desenvolvimento da cultura da soja para o estado do Paraná - Brasil. Engenharia Agrícola, 36(1), 126-142. https://doi.org/10.1590/1809-4430-Eng.Agric.v36n1p126-142/2016

Johann, J. A., Vieira, J. R., Lamparelli, R. A. C., \& Duft, D. G. (2013). Agrupamento de perfis espectro-temporais do índice de vegetação EVI/Modis para culturas agrícolas de verão entre os anos-safra 2004/2005 e 2007/2008 no Estado do Paraná. Anais XVI Simpósio Brasileiro de Sensoriamento Remoto - SBSR, 1703-1711. Foz do Iguaçu, PR, Brasil: Instituto Nacional de Pesquisas Espaciais (INPE).

Kenduiywo, B. K., Bargiel, D., \& Soergel, U. (2016). Crop type mapping from a sequence of TerraSAR-X images with dynamic conditional random fields. ISPRS Annals of Photogrammetry, Remote Sensing and Spatial Information Sciences, III-7(July), 59-66. https://doi.org/10.5194/isprs-annals-III-7-59-2016

Kim, Y. (2010). Spectral compatibility of vegetation indices across sensors: band decomposition analysis with Hyperion data. Journal of Applied Remote Sensing, 4(1), 043520. https://doi.org/10.1117/1.3400635

Liu, J., Zhu, W., Atzberger, C., Zhao, A., Pan, Y., \& Huang, X. (2018). A Phenology-Based Method to Map Cropping Patterns under a Wheat-Maize Rotation Using Remotely Sensed Time-Series Data. Remote Sensing, 10(8), 1203. https://doi.org/10.3390/rs10081203

Mulla, D. J. (2013). Twenty five years of remote sensing in precision agriculture: Key advances and remaining knowledge gaps. Biosystems Engineering, 114(4), 358-371. https://doi.org/10.1016/j.biosystemseng.2012.08.009

Princeton University. (2016). Latin American and Caribbean Flood and Drought Monitor. $\begin{array}{llll}\text { Retrieved November } & 22, & \text { 2017, }\end{array}$ https://platform.princetonclimate.com/LAFDM/interface.php?locale=en

Prudente, V. H. R., Martins, V. S., Vieira, D. C., Silva, N. R. de F. e, Adami, M., \& Sanches, I. D. (2020). Limitations of cloud cover for optical remote sensing of agricultural areas across South America. Remote Sensing Applications: Society and Environment, 20(May), 100414. https://doi.org/10.1016/j.rsase.2020.100414

Prudente, V. H. R., Mercante, E., Johann, J. A., Souza, C. H. W. de, Cattani, C. E. V., Mendes, I. S., \& Caon, I. (2019). Use of terrestrial remote sensing to estimate soybeans and beans biophysical parameters. Geocarto International, $\quad 0(0), \quad 1-18$. https://doi.org/10.1080/10106049.2019.1624982 
Rouse, J. W., Hass, R. H., Schell, J. A., \& Deering, D. W. (1973). Monitoring vegetation systems in the great plains with ERTS. Third Earth Resources Technology Satellite (ERTS) Symposium, 1, 309-317. https://doi.org/citeulike-article-id:12009708

Santos, H. G. dos, Júnior, W. de C., Dart, R. de O., Áglio, M. L. D., Sousa, J. S. de, Pares, J. G., ... Oliveira, A. P. de. (2011). O Novo Mapa de Solos do Brasil: Legenda Atualizada escala 1:5.000.000 (p. 67). p. 67. Retrieved from http://www.cnps.embrapa.br/solosbr/publicacao.htm

Sharma, L., Bu, H., Denton, A., \& Franzen, D. (2015). Active-Optical Sensors Using Red NDVI Compared to Red Edge NDVI for Prediction of Corn Grain Yield in North Dakota, U.S.A. Sensors, 15(12), 27832-27853. https://doi.org/10.3390/s151127832

Souza, C. H. W. de, Mercante, E., Johann, J. A., Lamparelli, R. A. C., \& Uribe-Opazo, M. A. (2015). Mapping and discrimination of soya bean and corn crops using spectro-temporal profiles of vegetation indices. International Journal of Remote Sensing, 36(7), 1809-1824. https://doi.org/10.1080/01431161.2015.1026956

Stocker, V., Souza, E. G. De, Johann, J. A., Beneduzzi, H. M., \& Silva, F. de O. e. (2019). EFFECT OF HEIGHT, TILT AND TWIST ANGLES OF AN ACTIVE REFLECTANCE SENSOR ON NDVI MEASUREMENTS. Engenharia Agrícola, 39(spe), 96-108. https://doi.org/10.1590/1809-4430-eng.agric.v39nep96-108/2019

Sun, T., Fang, H., Liu, W., \& Ye, Y. (2017). Impact of water background on canopy reflectance anisotropy of a paddy rice field from multi-angle measurements. Agricultural and Forest Meteorology, 233, 143-152. https://doi.org/10.1016/j.agrformet.2016.11.010

TRIMBLE. (2010). GreenSeeker 505 Hand held Sensor User Guide (p. 18). p. 18.

Viana, O. H., Mercante, E., Andrade, M. G. De, Cattani, C. E. V., Bombarda, F. F., \& Boas, M. A. V. (2018). Potential of hyperspectral remote sensing to estimate the yield of a Crambe abyssinica Hochst crop. Journal of Applied Remote Sensing, 12(1). https://doi.org/10.1117/1.JRS.12.016023

Viana, O. H., Mercante, E., Felipetto, H., Kusminski, D., \& Bleil Jr, H. G. (2017). Characterisation of the Spectral-Temporal Pattern of the Crambe Crop Using Hyperspectral Sensors. Journal of Agricultural Science, 9(11), 220. https://doi.org/10.5539/jas.v9n11p220

Whitcraft, A. K., Vermote, E. F., Becker-Reshef, I., \& Justice, C. O. (2015). Cloud cover throughout the agricultural growing season: Impacts on passive optical earth observations. Remote Sensing of Environment, 156, 438-447. https://doi.org/10.1016/j.rse.2014.10.009

Willmott, C. J., Robeson, S. M., \& Matsuura, K. (2012). A refined index of model performance. International Journal of Climatology, 32(13), 2088-2094. https://doi.org/10.1002/joc.2419

Yao, X., Yao, X., Jia, W., Tian, Y., Ni, J., Cao, W., \& Zhu, Y. (2013). Comparison and intercalibration of vegetation indices from different sensors for monitoring above-ground plant nitrogen uptake in winter wheat. Sensors (Switzerland), 13(3), 3109-3130. 
https://doi.org/10.3390/s130303109

Zheng, H., Cheng, T., Yao, X., Deng, X., Tian, Y., Cao, W., \& Zhu, Y. (2016). Detection of rice phenology through time series analysis of ground-based spectral index data. Field Crops Research, 198, 131-139. https://doi.org/10.1016/j.fcr.2016.08.027

\section{Copyright Disclaimer}

Copyright for this article is retained by the author(s), with first publication rights granted to the journal.

This is an open-access article distributed under the terms and conditions of the Creative Commons Attribution license (http://creativecommons.org/licenses/by/4.0/). 